\title{
"All Aboard!": \\ The Role of the Railroads in Protecting, Promoting, and Selling Yosemite and Yellowstone National Parks
}

\author{
Joshua Scott Johns \\ Lancaster, Pennsylvania
}

B.A., Penn State University, 1993

A Thesis presented to the Graduate Faculty of the University of Virginia in Candidacy for the Degree of Master of Arts

Department of English

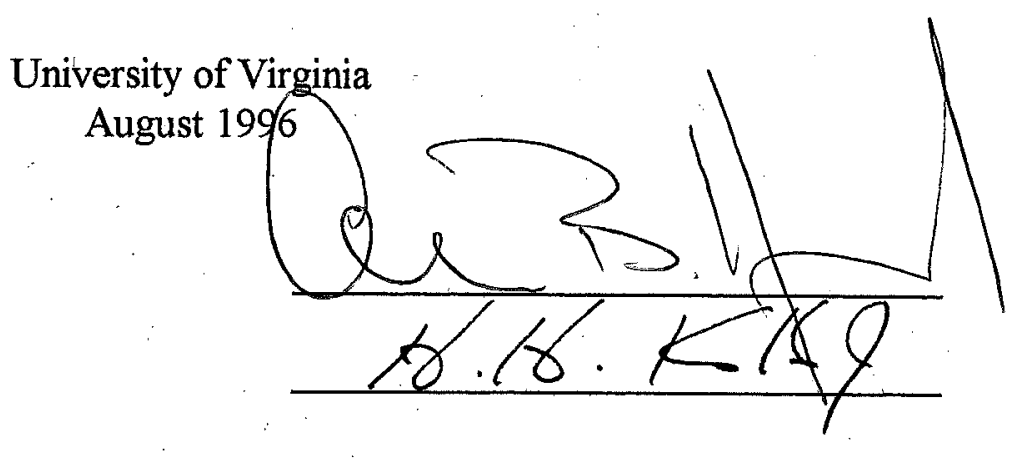




$$
\begin{aligned}
& \text { ALD } \\
& \text { Masters } \\
& \text { English } \\
& 1996 \\
& .163
\end{aligned}
$$




\section{Table of Contents}

Abstract

Introduction 1

Discovery and Invention in Yosemite $\quad 5$

$\begin{array}{ll}\text { The Grand Canyon of the Yellowstone } & 17\end{array}$

$\begin{array}{lr}\text { Yosemite and Yellowstone in Railroad Advertising } & 27\end{array}$

$\begin{array}{ll}\text { Empire Building: 1873-1883 } & 27\end{array}$

Expanding the Target Market: 1883-1900 36

Boom Times in “America's Playgrounds”: 1900-1916 47

$\begin{array}{lr}\text { Conclusions } & 54\end{array}$

$\begin{array}{lr}\text { Works Cited and Bibliography } & 57\end{array}$

This project is the text version of a thesis designed for presentation on the world wide web. To view this thesis in its intended medium, with accompanying graphics of advertisements and paintings discussed in the paper, please access the web and point your browsers to the URL for American Studies at the University of Virginia: 


\section{“All Aboard!": \\ The Role of the Railroads in Promoting, Protecting, and Selling Yosemite and Yellowstone National Parks}

When Mark Twain viewed Albert Bierstadt's painting The Domes of the Yosemite in 1867 , he declared it "altogether too gorgeous," adding that "as a picture, this work must please, but as a portrait, I do not think it will answer. Portraits should be accurate." Despite Twain's suspicion of the lack of verisimilitude in the painting, the New York audience was eager for images of the territory west of the Mississippi. Paintings and sketches of places like Yosemite and Yellowstone suggested that America possessed scenery more majestic than Europe's and that despite the chaos of the Civil War and its aftermath, America was still destined for greatness. The founding of the National Park idea in these two very different Wests was a process by which images of the West were inserted into the national imagination. Yellowstone and Yosemite were dedicated with the idea that wilderness formed an integral part of the American identity, but they were also places sponsored and promoted by the railroads to court investors and maximize profits. From the earliest days of discovery to the crucial National Park Act of 1916, the process of park development was shaped by needs of the railroads--from acquiring investors to selling mass-market tourism, they modified their advertising strategies to win the patronage of new passengers with the promise of fulfilling their expectations of the West in "America's playgrounds." 


\section{Introduction}

As late as 1850, much of the territory west of the Mississippi was only roughly sketched geologically and geographically. Exploratory expeditions modeled after that of Lewis and Clark became the primary taxonomical tools for the largely unexplored and unsettled Rocky Mountain West. Until the Civil War interrupted these surveys, most expeditions were sponsored by the military in order to settle territorial disputes or provide cartographic information for proposed wagon routes. By 1867 , renewed interest in exploration for settlement and economic development emerged. Between 1867 and 1870, the United States sponsored what were known as the Great Surveys, four extensive campaigns of comprehensive research on the western landscape sponsored by the government but subsidized by private enterprise as well.

Rail companies were among the largest private contributors. Railroads had a primary interest in detailed geographical information and speculated on survey results which would facilitate their marketing enterprises in the West, and they counted on profits from their investments, both in offering real estate from their land grants and then in hauling the raw materials of farming and mining from the settled territories. Northern Pacific Railroad acquired 47 million acres between Lake Superior and the Puget Sound along a proposed line that spanned 1,975 miles, the largest land grant ever given to a railroad (Poor 471). Based on current rail costs in the 1860 's, the estimated construction cost per mile ranged from $\$ 17,000$ in the level eastern portions in Minnesota and the Dakotas; $\$ 30,000$ in the high plains of Montana; and nearly $\$ 50,000$ in the Northern 
Rockies of Idaho and the Cascades in Washington. The Central Pacific Railroad, contracted to build from San Francisco east to meet the Union Pacific, estimated a cost of over 97 million dollars, only a quarter of which was to be paid in government subsidy (Poor 425).

The railroads were justifiably optimistic about their future prospects for selling real estate that could be developed to provide valuable raw materials to haul. Tales of California's fertile land and agreeable climate compared it to the Mediterranean, and rumors of the moist climate and exotic land in the Pacific Northwest painted tropical pictures in the minds of Easterners who nicknamed it "Jay Cooke's Banana Belt," referring to the chief financier-cum-chief publicist of the Northern Pacific Railroad (Harnsberger 46). The railroads marketed each region along their lines to sell the land for settlement, often exaggerating or distorting the truth about the territory in order to make it more appealing to immigrants and disgruntled Eastern urbanites. "The Old Northwest" of Minnesota and the Dakotas was touted as the most fertile land in the New World, and California became "Cornucopia of the World" in advertisements from Southern and Union Pacific. These schemes worked, and scores of settlers, almost all of them unaware of the harsh realities of life in these territories, rode the rails west to claim their land.

Selling real estate and speculating on stable economic success from future markets for freight and resources did not address the immediate necessities of building the railroad. The high price of transcontinental railroad construction required immediate capital, and rail companies could only sell real estate once the track to available land was completed. Primary railroads like Northern, Union, and Southern Pacific each offered 
almost 100 million dollars in available stock, an amount roughly equivalent to their costs of construction. From the 1860 's to the mid-1880's, railroad companies needed to work just as hard at attracting investors as they did to attract future settlers. In order to win the financial support of potential shareholders, the railroads needed a way to entice the wealthy into riding the railroads and then persuaded them into believing that buying stock in the railroad was a solid financial investment.

A well-developed campaign to attract settlers and sell real estate was part of proving to investors that the railroads would enjoy future prosperity, but scattered along any Western rail line were regions of rugged mountains, steep slopes, and poor soil unsuitable for settlement. Initial reports dating to 1855 claimed that these areas were more majestic and awe-inspiring than any Swiss scene. As tales of regions like Yosemite and Yellowstone traveled east and fascinated the public, the railroad companies seized the opportunity to maximize the utility of their holdings and capitalize on the idea that selling scenery could be as profitable as selling arable land. Although the popular view of land at the time, as Alfred Runte succinctly states it, held that "wealth of resources, not of scenery, had become the nation's ultimate measure of achievement," the railroads saw Yosemite and Yellowstone as different kinds of economic resources that they could use for tourism (Runte NP 53).

Because of railroad interest in sponsoring scenic parks in the West to attract investors and build a market for passenger travel, the railroads became the most active and effective supporters of the idea of creating National Parks in America. Despite the best intentions of preservationists and the gradually emerging notion that the American 
wilderness represented one expression of a national heritage, the National Park System of today is a product of the needs of the railroads in the Nineteenth and early Twentieth centuries. The railroads did not consciously create protected spaces of Western ecology or American heritage, but instead took advantage of popular trends in perceptions of the West to maximize their profits through tourism, visitation, and investment.

Advertisements for travel to Yellowstone and Yosemite illustrate the ability of Northern and Southern Pacific Railroads to shape and respond to interest in the West in order to encourage rail travel and park visitation to meet their economic needs. From the 1860 's to the 1880 's, the railroads targeted an elite audience in order to win their support, and the publicity they stirred before rail construction and the advertisements they sponsored after its completion promised the elite an unparalleled experience on the exotic American frontier with plenty of luxury to make the trip palatable. In the 1890 's, both the needs of the railroads and the character of the West were changing, and the railroads shifted their advertising strategy to a mass- market approach to target new tourists who could help the rails achieve greater returns on their tourism facilities in Yosemite and Yellowstone. Finally, as the West came of age economically and posed threats to the issue of park preservation, the railroads led the final impetus to legislate a central government bureau to protect the parks from development--and protect the substantial investments and profit centers the railroads had in the national parks. 


\section{Discovery and Invention in Yosemite}

"Whoever wishes, for health's sake or for any other reason, to change the sceneries or the objects and associations of his life, should set off, not for Europe, but for California. And this the more certainly, if he is a loving and sharp observer of nature; for nature meets us here in moods entirely new; so that we have even to make her acquaintance over again; going back to be started in a fresh childhood."

Horace Bushnell, The New Englander, 1868 (Anderson)

America was introduced to the Yosemite Valley in 1851, when a small unit from the Mariposa Battalion stumbled into the valley while on a mission to remove indigenous inhabitants to a nearby reservation. After completing their task, the troop named the valley the "Yo-Sem-I-ty" in honor of the native tribe they had just forcibly removed. The inadvertent discovery of the valley and the significance then assigned to it by the Battalion established a pattern of accidental discoveries and invented significance which replayed throughout Yosemite's development into a premiere tourist destination and primary selling point for the Union and Southern Pacific railroads. Activity at Yosemite during the 1860 's set precedents for many "inventions" to come. Images of Yosemite helped transmit carefully designed views of the Western landscape to the East, the land of Yosemite itself was pitched as new source of cultural pride in America's beautiful and variegated landscape, and the importance of this 1000 square mile territory was significant enough to justify its removal from the public domain as America's first nature preserve. But behind the cultural invention, a steamship company and the Union Pacific Railroad were looking for ways to bring people West to newly settled territories, and their own discovery and invention in Yosemite made its protection possible. 
Tales of the valley's magnificence spread throughout California, and in 1855, a group of luckless forty- niners led by James Mason Hutchings entered the region and discovered a different kind of gold than the one they originally sought in the West. Rumors of a 1000-foot waterfall and sheer mountain walls soaring thousands of feet above the valley floor were circulating throughout California, most likely by men from the Mariposa Battalion, and Hutchings set out to find it. If the valley was as impressive as the stories about it suggested, Hutchings believed he could open it to tourism full-time. No one in Hutchings's party knew the location of the rumored "Yo-Sem-I-ty" or "Yo-Hamite," valley, but based on the area's advance publicity, they recognized it when they saw it. When the group entered the valley in June of 1855 and stood below the 1,430-foot Yosemite Fall, Hutchings wrote that it was "beyond the power of language to describe the awe-inspiring majesty of the darkly frowning and overhanging mountain walls of solid granite that here hem you in on every side, as though they would threaten you with instantaneous destruction if not total annihilation, did you attempt for a moment to deny their power" (Anderson).

Hutchings immediately grasped the tourist potential in this landscape and set out to promote it as proof that America could compete with Europe for the traveler seeking scenic beauty . During the 1850 's, the wealthy tourist who sought sublime scenery and mountain vistas headed for Switzerland, believing in the Romantic view that historical significance or evidence of a centuries-old civilization enhanced the beauty of a landscape. Yosemite lacked that kind of historical appeal, but the sharp rises of the mountains and the waterfall believed to be the highest in the world suggested that this 
landscape had more natural beauty to offer than the resort at the famed Swiss valley, the Lauterbrunnen. Hutchings began surveying the area for the construction of a hotel on the order of ones in Eastern resorts such as Niagara or the White Mountains in New Hampshire with the belief that if Americans were willing to pay for the falls at Niagara or the rolling mountains of New Hampshire, they would be eager to see American scenery on the order of Switzerland with a waterfall as high as nine Niagaras.

In order to promote this valley, Hutchings included the young artist Thomas Ayres in his party, and he became the first known person to sketch the features of the Yosemite Valley. Hutchings invited Ayres because if Yosemite could be made into a resort, Hutchings knew that Ayres' drawings would be instrumental in future advertising. During the summer of 1855, Ayres sketched while Hutchings surveyed, and by October of that year, Hutchings copyrighted the sketches and announced his plans to begin publication of California, a promotional magazine aimed at attracting tourists to Yosemite. In 1857, Ayres's sketches reached New York, and although his art was somewhat pedestrian and lacked the degree of technical development often associated with the work shown in galleries or museums at the time, Harper Brothers saw that interest in Yosemite might sell magazines and announced their intention to hire Ayres to complete more portfolios of the valley for a series of articles on California. During the return trip West by steamer, however, Ayres died in a shipwreck.

Between 1855 and 1860, Hutchings advertised Yosemite in the San Francisco area and in publications circulated on the East coast. As more travelers, explorers, and ex-forty-niners entered Yosemite and offered moving testimonials to its grandeur which 
were published in Eastern periodicals, public interest in Yosemite rose. Written reactions to Yosemite often read like this opinion, published in the Eastern periodical, The Country

\section{Gentleman:}

I never before felt so anxious to write, and so utterly incompetent to do justice to my subject. Of all the scenery I have ever witnessed, I never saw anything so magnificent. Often, while gazing with amazement on the huge mountains and the stupendous falls, I repeated the passage of Scripture: "Great and marvelous are thy works, Lord God Amighty." Never before was I so deeply impressed with the omnipotence and wisdom of Deity. (Anderson)

Glowing exhortations like this one prompted adventurous Easterners to make the arduous overland journey to California to see Yosemite but also to see California itself, a territory which was often described in similarly rapturous prose. Eastern men of power and position, such as New York Tribune editor Horace Greeley, New Englander writer Horace Bushnell, and former Boston author and minister Thomas Starr King each made the journey and seconded the praises already published. Greeley and King were important visitors because both were well-known and respected figures in Eastern society, and each had the position to provide publicity for Yosemite and generate interest in travel to the valley among the Eastern public. Greeley's travel journal An Overland Journey was published in 1860, and King's reactions appeared in letters to the Boston Evening Transcript that same year. Both accounts were widely read, and Yosemite became a subject of discussion in the East. Each author praised the scenery of Yosemite and the West, and King promised that "the blended majesty and beauty of it apart from the general sublimities of the Yo-Semite gorge would repay a journey of a thousand miles," a distance perhaps poorly chosen since Boston travelers would have had to endure three 
thousand miles by stagecoach and pack horse in order to see it.

People were eager to see Yosemite, however, and in 1862, photographer Carleton Watkins provided visual proof that Yosemite's landscape was real in an exhibit at Goupil's Art Gallery in New York. The apparently real but still very dramatic mountain scenes contrasted sharply with the Civil War photographs from Matthew Brady's studio exhibited at the same gallery a few months before the Watkins exhibit (see Anderson). The views of the Eastern landscape from the cameras of Brady and Timothy O'Sullivan showed scenes of battle and fields littered with the casualties of war, but the views of Yosemite were peaceful, majestic, and above all, empty. According to the photographic choices of Watkins, 'scenes of Yosemite showed expansive valleys, rugged mountains, and the total absence of human habitation. This was, in Bushnell's words, a mood of nature "entirely new" to an American public that valued landscapes marked by some evidence of civilization. Juxtaposed with the alternatives of Brady's photographers, images of the West depicted a place so remote and empty that it was free of the political and social turmoil of the war-torn East and held only the promise of the chance to begin again, on political and economic levels. Of course, the history of this seemingly Edenic and empty valley was rooted in violence, in the forced evacuation of the Native American tribes who lived there. The significance of the Western landscape in the national imagination is much more complex than this episode may suggest, but the impact of the contrasting images of East and West, along with the verbal descriptions of Yosemite that compared it to Switzerland and then claimed it was more impressive than the Alps, stimulated the imaginations of Eastern residents and piqued their interest in seeing it for 
themselves.

This growing interest in vacationing in California instead of Europe represented a demand for transportation that was not easy to meet in 1862 , but the newly organized Union and Central Pacific Railroads would soon provide the means to see the country without having to undergo the strenuous ordeal of the overland journey by stagecoach. During the 1860 's, Union and Central Pacific railroads were building the nation's first transcontinental railroad. The 97 million dollar cost of this undertaking warranted the sale of 100 million dollars in stock, and both railroads were in search of suitable investors. Central Pacific was building east from Sacramento, a city within reasonable proximity of the Yosemite Valley. When discussion about Yosemite began to emerge in New York's upper echelon society and articles about it appeared in Harper's, Scribner's, and Eastern newspapers, the railroad executives made another discovery and invention in the valley as they exploited it to entice the wealthy of New York to experience the railroads and hopefully invest in their construction.

The railroads were after men who had made their fortunes in businesses like shipping, mining, foundries, and dry goods-all industries which could benefit from the railroad's ability to bring in raw materials from the nation's interior and haul finished products back to the frontier communities. The central plains were sold as prime farmland, and the mineral-rich lands of Nevada and Utah were sold for silver and copper mining. The railroad had every reason to be confident about the economic potential of development in the West, but the interest in Yosemite and the popularity of scenic tourism in the 1860 's opened another possibility for future profit through passenger 
service. Yosemite could serve as a relaxing destination for speculation trips with investors curious to see the economic resources the railroads claimed elsewhere. Once potential investors had seen the value of the railroad in business terms, they could also see the beauty of a place like Yosemite, where they could rest and vacation after only a week on the train.

Although it is not documented, it is possible that a Union Pacific investor or executive could have been present at the Watkins exhibit at Goupil's in December 1862, since gallery showings attracted the wealthy clientele the railroads courted and the Yosemite photographs in particular would have been of interest to railroad investors who knew of its proximity to the California segment of Central Pacific's connecting railroad. One man who was most likely in attendance was the painter Albert Bierstadt, who was already a highly regarded landscape painter of the Alps and Rocky Mountain scenery at the time of the Watkins exhibit. Whether Bierstadt was at Goupil's that evening or not, he had the opportunity to see the photographs and expressed his interest in painting the Sierras himself. Linda Ferber describes the artist as "an adept lobbyist" when it came to seeking opportunities or winning favors that would help to advance his career, and he had a reputation for both being well-connected socially and skillfully using those connections when necessary (Anderson and Ferber 43). It is not clear how Bierstadt planned his trip to California, but when he announced his interest in travel to the West, Union Pacific was eager to sponsor his passage, and Leland Stanford and Collis Huntington of Central Pacific became his two most valuable patrons.

In 1863, Bierstadt and popular writer Fitzhugh Ludlow, author of the bestseller 
The Hasheesh Eater, traveled to the West as guests of Union Pacific. Bierstadt sketched scenes of the West and Ludlow provided the narrative to accompany them. The resulting portfolio would be featured in magazine articles in the East and became the basis for Ludlow's book Heart of the Continent. The two traveled by Union Pacific to its 1863 terminus at Atchison, Kansas, and from there the railroad arranged for a stagecoach to follow the proposed rail line to San Francisco. Union Pacific counted on Bierstadt's talent to render the Western landscape in vivid color on his canvases and they banked on his popularity to draw the wealthy audiences to future gallery showings in New York to see the California country.

Both the railroads and Bierstadt were pleased with the trip. The Sierras proved profoundly inspirational to Bierstadt's inventive artistic eye, and the exaggerated scenes that resulted from the trip allowed the railroads to capitalize on public interest generated by Bierstadt's dramatic and fanciful style. Bierstadt's largest and most popular canvas from the Yosemite is The Domes of the Yosemite, painted in 1867. Although Mark Twain criticized the nine-by-fifteen foot canvas for being "altogether too gorgeous" and "considerably more beautiful than the original," the overall Eastern response was favorable (Prown 14). Bierstadt brought out the possibility of this landscape only hinted at in Watkins' photographs by relying on familiar conventions of landscape painting in America to allow viewers to interpret the importance of the scene he painted. Audiences familiar with conventions in American art during the Nineteenth century could recognize the significance of Bierstadt's compositional choices. To understand Bierstadt's message about Yosemite, the viewer first had to recall works like The Oxbow, an 1836 painting by 
Thomas Cole. Cole's painting, when compared with Bierstadt's Domes of the Yosemite showcases a similar use of light and shadow to demonstrate the tension between civilization and the wilderness. The wilderness, shadowed and clouded over to the left, is on its way to becoming civilized by the approaching pastoral scene of agricultural progress and human design, shown bathed in glowing light on the right.

In Domes, however, the tension between wilderness and civilization is much more subtle. Bierstadt also employs the use of suffisive light in his scene, but it illuminates the wilderness of the Yosemite Valley instead of a "civilized" pastoral valley. Through this play on light and atmosphere, Bierstadt suggests that civilization springs from the wilderness rather than contends with it. Domes suggests the possibility of Yosemite and landscapes like it to become civilized and familiar, and Bierstadt was inventing a visual myth of creation--or perhaps re-creation--for America by portraying the Western landscape as an empty vessel waiting for American ingenuity and productivity to civilize it, fill it, and make it bloom with economic prosperity. Union Pacific enjoyed ample publicity for California through Bierstadt's popularity, and the reactions sparked by the Yosemite canvases showcased by the artist brought the valley into the discussions in the East again.

While Union Pacific courted investors and continued construction during the summer of 1863, Israel Ward Raymond, a representative for the Central American Steamship Line, visited Yosemite and announced his plans to lobby for its protection from unchecked exploitation, even though he had the more subtle exploitation of selling scenery in mind. Ward's company ferried passengers to the California coast, and he 
realized the opportunity to feature Yosemite in travel advertisements. Central American Steamship was already in business and could take advantage of the emerging interest in travel to Yosemite because the railroads were still years away from completion. Raymond sensed the profitability of Yosemite as a tourist destination, but he knew that continued interest relied on Yosemite's protection from the rampant consumerism which had blemished Niagara Falls. The falls were recognized as a supreme natural wonder around the world, but commercial opportunists were free to take advantage of its popularity. The resulting influx of profiteers during the 1830's and 1840's became known as "the shame of Niagara" around the country, and the brink of the falls was crowded with the architectural pollution of hotels, shops, and industries. Tourists who came to Niagara criticized the commercialization, and British travel writer Sir Richard Bonnycastle said that "it requires very little to show that patriotism, taste, and self-esteem are not the leading features in the character of the inhabitants in this part of the world" (Runte, NP. 8). Yosemite, which was often described in terms of Niagara for the ease of comparison, was still too remote to succumb to the same degree of profiteering, and Raymond wanted to ensure that the valley would always be protected, and thus always be desirable as a tourist destination.

Raymond managed to rally a group of concerned Californians to lobby for Yosemite's protection. The group sought protection based on the argument that if Americans hoped to substitute their magnificent wilderness for an ancient cultural civilization, they "would have to do better than allow the redwoods, Niagara Falls, or any other landmark to be auctioned off to the highest bidder" (Runte, NP 28). Parks historian 
Alfred Runte points out that Raymond used a curious phrasing in his proposal for protection which later emerged in the Congressional statement. Raymond wrote "let the wonders of Yosemite be inalienable forever," a word choice which suggests that Raymond sensed the importance of establishing cultural credibility for this new idea of protecting and preserving American land. The phrase evokes the patriotism behind the "inalienable rights" from the Declaration of Independence and reflects Raymond's insistence on constructing a cultural heritage through landscape. Of course, Raymond had a great interest in turning Yosemite in to a new source of national pride because his company would benefit from throngs of curious tourists eager to see what made Yosemite special enough to become the first national monument. Congress was convinced of Yosemite's importance and the act, signed in the midst of the Civil War on June 30, 1864 by President Lincoln, declared that Yosemite Valley would "be held for public use, resort, and recreation.inalienable for all time" (USDI:1991 10).

Yosemite was most importantly a precedent for future railroad enterprise in the West. Discoveries in Yosemite in terms of railroad profits were largely speculative ones. Union Pacific needed to make its connection with Central Pacific before it could actually measure the success of having a place like Yosemite to attract investors and tourists, and since the rail lines were still separated by the Rockies in 1864 , they could not call the park their own. The railroads sensed the importance of Bierstadt's visit to convey the atmosphere of Yosemite to the wealthy Eastern audience who might be persuaded to investigate the territory soon to be traversed by the railroad and invest in the venture. Raymond's efforts, motivated by the possibility of a new marketing strategy, allowed for 
the unprecedented removal of land from the public domain for the purpose of protecting scenery. Although motivated by profit, he persuaded Congress that the land was majestic

' enough to serve as a monument to the American character, and his appeal was successful.

Yosemite's protection was less a strategy than an experiment, but it was intriguing enough to prompt the Northern Pacific Railroad into refining the idea into a strategy when Yellowstone was surveyed in 1871. 


\section{The Grand Canyon of the Yellowstone}

"In this tract of about 3000 square miles, there are manifestations of force so enormous that its mathematical expression could convey no idea to the ordinary mind. Nothing but the imagination can grapple with the problem, but the imagination most stimulated and exuberant carries one but a little way on the road to truth."

--Harper's Weekly, 1893.

Stories of Yellowstone had reached the East coast as early as 1810, when John Colter, a member of the Lewis and Clark team who remained in the West, wrote of an odd territory the Native American Minnetaree tribe called "mi tsi a da zi," or "Rock Yellow River." Reports of foul-smelling vapors and volcanic craters that bubbled with clay circulated sporadically among other trappers and explorers who claimed to have seen the place they called "Colter's Hell," but credible accounts of the region were not published until the completion of the Washburn-Doane Survey and the Hayden Expedition in 1870 and 1871. The sensational accounts of Yellowstone's geology fascinated Eastern audiences, and publicity for the finds in the area was plentiful. Newspapers, magazines, and lectures both instructed and intrigued Eastern residents with the tales of shooting geysers, boiling streams, and sulfuric pits which resided with majestic waterfalls, stunning canyons, and rugged mountain peaks in excess of 10,000 feet. With topography like this, interest in Yellowstone was easy to encourage, and executives at Northern Pacific railroad realized that they had planned their track just north of something unique.

Northern Pacific Railroad was still in its organizational stages during Yosemite's establishment as a national preserve in the mid-1860's, but the offices of Jay Cooke \& 
Company, the railroad's chief financiers, noticed the park's significance for both Central American Steamship Company and Union Pacific Railroad. Northern Pacific offered 100 million dollars in stock in 1868 to finance its construction, and the railroad management dedicated itself to enticing investors. Northern Pacific's venture differed from Union Pacific's in several ways, and the company's advertising strategy was more comprehensive as a result. The railroad crossed some of the most desolate and remote territory in the nation, particularly along track in the Dakotas and Eastern Montana. Although land at its origin in Minnesota and the territory at its Western terminus in Tacoma, Washington were well-adapted for agricultural and timber uses, large sections of the railroad's land suffered brutal winter weather and would have required years of cultivation and tempering to become productive for agricultural use.

Reasons for Northern Pacific's aggressive advertising and publicity are speculative at best, but many historians of the railroad agree that the primary reason Northern Pacific's name appeared so often in newspapers and magazines was that Jay Cooke was its financier. Cooke was the head of a Philadelphia banking house that had provided most of the funding for the Union effort in the Civil War, and he was known for having a flair for generating publicity about any project or investment that interested him. He was well-connected politically and socially, and he was adept at using those connections to his advantage. Cooke was excited by the results of the 1870 Washburn survey, and in 1871 , he made the first important connection in the publicity machine he created to stimulate interest in Yellowstone for the benefit of the railroad.

In 1870, Scribner's Magazine acquired a story called "The Wonders of the 
Yellowstone," a journal from the Washburn-Doane expedition written by Nathaniel P. Langford. Scribner's assigned their illustrator, Thomas Moran, to provide sketches for the story, and Moran was so intrigued with the sights Langford described that he grew eager to see the territory for himself. During the late winter of 1871, renowned geologist Ferdinand V. Hayden received a government subsidy to organize his own survey team to chart the headwaters of the Yellowstone River the following summer, and Moran formulated a strategy to include himself in the group. Determined to make his way west, Moran solicited financial support from Scribner's in exchange for sketches and regular reports from the survey. The managers were skeptical, but after Jay Cooke learned of Moran's interest and agreed to loan the artist $\$ 500$ and secure a place for him on the Hayden team, Scribner's matched Cooke's loan and Moran joined Hayden in Virginia City, Montana.

Little did Moran realize that he had not only succumbed to the maneuverings of a number of powerful men, but had also stumbled into one of the grandest industrial and political schemes of the Nineteenth century. Jay Cooke wanted Moran's visual talents to bring pictures of Yellowstone to the East much as Union Pacific relied Bierstadt's work to portray Yosemite so vividly for the New York audience who came to see his paintings. Bierstadt and Union Pacific had.Fitzhugh Ludlow to capture Yosemite in prose, and Moran and Northern Pacific had Nathaniel Langford. Langford was campaigning to be governor of the Montana territory and had his own economic interests in Yellowstone, but he had also been solicited to write his book by Jay Cooke, who arranged for its publication and coached the author on his many lectures throughout the East--lectures 
which ended with praises for the Northern Pacific Railroad's planned track through southern Montana, just above Yellowstone's North Entrance. Langford's work had further inspiration as well since he was the brother-in-law of two of Northern Pacific's largest investors, Minnesota businessman James Wickes Taylor and Governor William Marshall of Minnesota, the state where the railroad originated. Ferdinand Hayden's expedition was supported by government funding, but since funds were limited, he relied on the generosity of the rail magnates to receive free transportation to the West for his party. Additionally, he aspired to lead future expeditions and, with the financial support and political clout of Jay Cooke behind him, his chances were good. When Moran presented the letter from Cooke, Hayden was more than willing to accept the artist into his already crowded group because with Cooke's favor and Moran's talents, Hayden's expedition would receive ample publicity. Moran, of course, desired fame and security as an artist and recognized that Cooke's backing, Hayden's acquaintance, and widely publicized accounts of Yellowstone would thrust his paintings into the public spotlight. With every player in his proper place, Hayden's expedition departed Virginia City for Yellowstone with Moran and famed landscape photographer William Jackson in tow (Kinsey 68-70). Hayden's survey findings confirmed what Jay Cooke had suspected: Yellowstone was as unsuited for traditional economic exploitation as the Yosemite Valley had been. Hayden, one of the most respected and knowledgeable geologists of his time, gave his assurances that the land in the Yellowstone area was worthless for anything but recreation and geologic study. The land was devoid of valuable minerals, its stands of timber were erratic and not of particularly good quality, and the terrain was too steep and sparsely 
vegetated for grazing land. Essentially, the only value Yellowstone possessed was in entertainment. Northern Pacific owned land just north of the Yellowstone, and in a letter from Jay Cooke's office to Hayden late in 1871, Cooke wrote that: "Judge Kelley [Senator William Darrah Kelley of Philadelphia, a friend of Cooke] has made a suggestion which strikes me as being an excellent one, viz: Let Congress pass a bill reserving the Great Geyser Basin as a public park forever--just as it has reserved that far inferior wonder the Yosemite Valley and big trees" (Kinsey 58). Cooke and Hayden agreed that Yellowstone's showcase of natural wonders was priceless and therefore should receive federal protection.

Using Yosemite as a precedent for federal protection, Northern Pacific Railroad adopted Yellowstone as its own and set out to establish a Western resort in the region. Although Yosemite had been protected by an act of Congress, the federal government granted park management to the state of California. Cooke, Hayden, and Langford discussed the Yellowstone proposal with Senator Henry Dawes, a vociferous proponent of Yosemite's protection and a good friend of Hayden. Langford feared that Yellowstone would fall to Wyoming for management since it was technically within that territory's boundaries. Langford wanted control of Yellowstone turned over to the Montana government so that his territory could benefit from developing the area for tourism. Langford argued that since the headwaters of the Yellowstone River were on Montana soil and the territory had hosted the government survey teams in its towns, Montana should be granted management privileges. Of course, if Montana had rights to the park, then Langford's political power could assist Northern Pacific's interests in Yellowstone, 
and Cooke supported Langford's proposal. Cooke's primary objective for Yellowstone was to protect it and get access to it as a nature park for tourism. He was also aware that its protection and promotion might also encourage potential investors to forego a holiday in Europe so that they could view the Yellowstone instead--and offer their financial support to Cooke and his railway.

The Yellowstone bill was introduced in Congress in January, 1872, and despite a few challenges, Dawes was able to keep the bill alive. His most serious challenge came when other Senators questioned how the proposed park boundaries would influence a recently designated Sioux reservation. The debate intensified, but Dawes confirmed the nation's right to claim that land when he replied "all of the treaties made by this commission are simple matters of legislation," and suggested that Congress redraw the reservation boundaries to accommodate the influential men like Cooke and colleague Senator Kelly, who had significant financial interests at stake (Haines 124). Congress was unwilling to assign management to either Montana or Wyoming since neither was admitted as a state, but on March 1,1872, Congress passed a resolution declaring Yellowstone's 2.2 million acres a National Park and appointed Langford the first Park Superintendent, a position which still allowed him to favor Northern Pacific's rail development in the 1880 's and 90 's by permitting railroad hotels within the park boundaries and advancing the connecting rail track to the park's Gardiner Gateway. Cooke's initial efforts were rewarded, but now he had to create proper publicity for Yellowstone among the wealthy society people able to afford travel to the West and more importantly, able to consider buying shares in the railroad. Cooke knew the value of 
visual materials in creating interest, perhaps recalling Bierstadt's success with his Yosemite paintings, and Thomas Moran's paintings would provide the opportunity for a publicity event which could draw Cooke's desired clientele. Moran had been turning his sketches into paintings since his return from the Hayden expedition, and he had indicated to Jay Cooke that he was working on a monumental canvas of the Yellowstone River canyon at approximately the same time the park bill was under consideration in Congress. Cooke saw this painting as an opportunity for the capstone of Northern Pacific's promotional publicity for Yellowstone. Stories about the region had circulated in the East for years, and once the park bill was signed, interest in Yellowstone as the first National Park would increase as newspapers and magazines published the news of the bill's passage. Eastern curiosity would be at its peak, and as Moran finished his canvas, Jay Cooke planned a grand public showing for the painting the first week of June 1872, circulating invitations to everyone he knew and sponsoring press releases about Moran's upcoming unveiling.

Moran's masterpiece from the Yellowstone expedition is entitled The Grand Canyon of the Yellowstone, which is the spectacular view of the Lower Falls through the deep chasm of yellowish-red sulfur-stained rock which earned Yellowstone its name. The New York Tribune reported that, as Cooke had hoped, the elite of New York attended the Clinton Hall showing in New York City. Directors of the Northern Pacific Railroad, "the press--the literati--the artists--all the rich people" came to view the magnificent seven-by-twelve foot canvas of the Yellowstone Canyon (Wilkins 6). In contrast to Bierstadt's tendency to paint a sense of sublimity and destiny in Yosemite's landscape, 
Moran's view of Yellowstone is much more realistically composed and lacks the invented iconographic significance of Bierstadt's work. Moran made meticulous studies of Yellowstone's geology and the painting shows a fairly accurate rendering of the canyon. In Moran's painting, the light in the scene radiates from the landscape itself instead of suffusing from the heavens, as Bierstadt's lighting does. This choice may reflect the fact that Yellowstone was unlike any other landscape known to Americans at the time, and comparisons to Swiss scenes or Hudson Valley views depicting the tension between civilization and wilderness would have been irrelevant. This landscape could not be civilized in an agricultural sense because of its volcanic geology, but its uniqueness as a wilderness could generate interest and had its own genuine significance; its landscape did not require the painterly inventions of the artist to bestow that significance or make the audience aware of it. By placing the human figures in the foreground, gesturing toward the canyon, Moran makes this strange landscape safe and familiar. The human presence in the scene reduces the threat of danger and makes the viewer aware of Yellowstone's possibility for human use and its capacity to attract human interest because of its own unique majesty. The human interest in question is that of tourism, and Cooke counted on public curiosity to see this uniquely American wilderness to stimulate travel on Northern Pacific.

Jay Cooke and Northern Pacific refined the process of park protection and travel publicity only haphazardly undertaken by Union Pacific and Central American Steamship, and their discovery set new standards for future railroad discoveries and park promotions during the late Nineteenth and early Twentieth centuries. The Yellowstone 
Park Act still left unfinished business for the railroads and for park protection. Montana residents were unhappy with the decision to place Yellowstone in the care of the federal government instead of with the territory, who already had the labor force and the means to develop the park for tourism by building roads and hotels from which the region could profit, and residents in Yellowstone Valley towns like Cooke City, Gardiner, Bozeman, and Livingston were not eager to assist the efforts of the railroad company they believed had taken their future livelihood. Editorials run in the Bozeman Avant Courier and the Helena Gazette stated that "it would have been better to have left its [Yellowstone's] development open to the enterprising pioneer who had already commenced the work," but the New York Times offered the view from the East that focused on the preservation aspect of Yellowstone, saying that "it will help confirm the national possession of the Yo-Semite and may in time lead us to rescue Niagara from its present degrading surroundings" (Haines 125-128).

Despite the difference of opinion in the matter of Yellowstone, its establishment provided a clear precedent for future park development. Although Yellowstone's federal possession was more the result of unstable territorial politics in Montana and Wyoming than it was a federally endorsed statement of Yellowstone's "national" significance, Northern Pacific's active role in its preservation and establishment provided the impetus for protection in the first place. What had occurred almost accidentally and inadvertently in Yosemite indicated a potential marketing strategy for the railroad industry in other rugged and inhospitable territory along their tracks. For the railroads, the most appealing draw for the parks was what the New York Times wrote in an 1872 article called "The 
Splendors of the West:"

Why should we go to Switzerland to see the mountains, or to Iceland to see the geysers? Thirty years ago the attraction of America was Niagara Falls. Now we have attractions which diminish Niagara into an ordinary exhibition. The Yo-Semite, which the nation has made a park.and the country of the Yellowstone, with their beauty, their splendor, their extraordinary and sometimes terrible manifestations of nature, form a series of attractions possessed by no other nation in the world (Haines 128).

The railroads believed that they had created a profit center to attract a new market in the tourist trade, and as the Eastern and Western crews approached their rendezvous points in the intermountain West, the railroads staged an elaborate and effective advertising campaign to sell travel on their rail lines and stock in their companies. 


\section{Yosemite and Yellowstone in Railroad Advertising}

\section{Empire Building: 1873-1883}

Jay Cooke's railway had grand plans for Yellowstone, and the advance publicity from Northern Pacific during the early 1870 's left the Eastern touring public eagerly anticipating future rail access to the region. Between 1868 and 1870, Central Pacific's "Big Four"--Leland Stanford, Collis Huntington, Charles Crocker, and Mark Hopkins-acquired the rights to local rail lines in California and organized the Southern Pacific Railroad in order to protect Central Pacific's competitive edge in California. The railroad would eventually connect San Francisco and Los Angeles and then cross the southern tier of the country to New Orleans to connect the profitable freight trade markets of the Gulf of Mexico ports and San Francisco. As Southern Pacific slowly advanced toward Los Angeles and the southern states, Northern Pacific built west from Minnesota, reaching Bismarck, North Dakota by 1873. The Southern Pacific route and Northern Pacific's connecting track to Yellowstone at Livingston, Montana might not have been more than a few years away, but Jay Cooke's banking house collapsed during the Panic of 1873. Because it was one of the wealthiest and most powerful financing house in the country, its failure created a ripple effect across the country, financially devastating the Northern Pacific and bringing all new construction on other railways to a halt.

Throughout the 1870 's, railroads scrambled for reorganization in their attempts to recover from the Panic and worked to attract new investors. Their initial efforts to create interest in the railroad enterprise by offering passenger service and enticing travel 
destinations like Yosemite and Yellowstone indicated that the parks could work to their advantage. The Yellowstone bill generated renewed discussions about Yosemite, and Jay Cooke's publicity events during 1871 and 1872 created an undercurrent of discussion in the popular press about the National Park idea. As the economy made its way to recovery along with the railroads, rail companies took advantage of the parks to attract the income of new investors and sponsors to complete the rail lines.

The traveler in the late 1870 's and 1880 's was primarily targeted as a potential investor, and the railroads marketed Yosemite and Yellowstone to the elite. One Northern Pacific advertisement that ran in Harper's Weekly even stated directly that the expense of the trip west was a guarantee that travelers would not be subjected to riding with "undesirable company" because only the wealthy high-society people could afford such a trip. This appeal to the elite sensibility not only made the trip desirable, but it also made it safe. The West in the 1870's and 1880's was not fully settled, and Yosemite and Yellowstone were remote enough to be somewhat intimidating to urban Easterners unaccustomed to and often uncomfortable with vast open wilderness. Railroad assurances that these passengers would travel in comfort and luxury to a premiere tourist destination with a class of people like themselves made the trip more palatable. To follow through on their promises, the railroads marketed the parks as elite locales exclusively for the enjoyment of the wealthy and advertised luxurious accommodations, both on and off the train, to court these important guests.

In 1880, Northern Pacific announced their "Yellowstone Park Line" and "North Coast Limited" routes, and Southern Pacific began to advertise their exclusive "Sunset 
Limited" line with through service from New Orleans to Los Angeles with the hopes of soliciting investments and winning future travel patronage from the wealthy, who paid high prices for tickets, Pullman cars, and special services like servants and private cars for large parties. The Pullman sleeping car, conceived by George Pullman and Andrew Carnegie in 1867 , came in many varieties but the most useful to the railroads in luring investors were those that featured plush interiors and comfortable appointments. The most prevalent form of this Pullman was the Palace car, which eased the discomfort of the train's lurches, bounces, and rocking with commodious chairs, sleeping quarters, and, for the most extravagant, parlors with settees, lounges, and occasionally a piano.

Northern and Southern Pacific invested in Pullmans and attracted visitors by showing them that they could travel across the continent in all the style and comfort of a fine New York sitting room. The luxury and privacy of a Pullman-not to mention the status-appealed to many of the targeted passengers, and as the elite traveler made new demands for accommodations such as fine dining and even "church cars" complete with ministers and small pump organs, the Pullman became more elaborate, more expensive, and more popular.

Both railroads employed similar advertising strategies and both featured exquisite "Pullman Service." Northern Pacific had sole access toYellowstone and also benefited from Nathaniel Langford's railroad-biased park management style, and the railroad had an easier time creating desired accommodations within the park. Southern Pacific, however, needed to compete with the more direct Central and Union Pacific line in enticing upper class passengers to ride the Sunset Route to the coast, and it also had to advertise 
Yosemite in a way that made it seem less like the remote wilderness it was and more like a gentrified wilderness made civilized by the presence of the railroad. The railway handled the challenge skillfully by producing advertisements which resembled Bierstadt scenes to makeYosemite safe and familiar to its Eastern market. During the 1880 's, San Francisco was known the Paris of the West and possessed an appeal that attracted and often won the affections of Eastern tourists. Travelers headed to the bay area bound for the posh Palace Hotel in San Francisco and the even more opulent Del Norte in Monterey. Many extended holidays in Northern California included a side trip to the Yosemite. The expense and difficulty involved in reaching the valley was a status symbol among the elite, and the rail lines happily took advantage of Yosemite's appeal when advertising their Sunset Line. Since the Yosemite was a popular vacation destination for many travelers headed west to San Francisco, the Southern Pacific marketed the Valley as its own, even though no railroad could claim direct access to the region until the Yosemite Valley Rail Line was built in 1907 with the assistance of Southern Pacific.

Southern Pacific could only work outside of Yosemite because its rail line ended at San Francisco. In advertisements during the 1880 's, the Southern Pacific played on the dramatic sense of scale showcased in Bierstadt's images of the 1860's and published advertisements that recalled the rapturous praise past visitors to the valley. The Southern Pacific knew its audience and marketed Yosemite to the "Romantic tourist," or the class of tourist who wanted to repose in nature but not participate in it too strenuously. Yosemite was a place of views and vistas; a valley where one could witness the sublimity of nature and ponder it without actually confronting it. Visitors stayed an average of four 
days, and then, as one traveler summarized the trip, after enjoying "a certain amount of the old wildness in the interior," they returned to San Francisco "to sit down to an eighto'-clock dinner that even Paris could not beat" (Pomeroy 53).

Yosemite thus acquired the reputation of being "the civilized wilderness," or the place where tourists could come to both bask in the magnificent scenery and indulge their fantasies of having conquered the wilderness with human achievement, especially within the commendable accommodations provided by James Hutchings and other hoteliers who had established small resorts in the valley to welcome tourists after a day of riding and gazing. Southern Pacific did little to discourage this opinion of Yosemite and exaggerated the image of the refined traveler in cool repose by the lakes, below the falls, or standing on the peaks of the mountains. Northern Pacific capitalized on Yellowstone's reputation for wildlife, but animal life in Yosemite was nearly ignored completely in favor of images which emphasized the more commercially appealing vistas of the valley and discarded any references to animal habitation. Yosemite's chief appeal was that it represented the perfect foil to the "dangerous" wilderness of the Rocky mountain West, where the hardships and the threats of nature associated with the frontier era were still too present to appeal to elite eastern audiences who travailed tirelessly to cultivate the affectation of refined European civility. This class of tourist wanted scenery on the order of Switzerland, but as Western historian Earl Pomeroy states it, "nature must not be too natural, or too close to the history of the long struggle of Americans across the continent," because these travelers did not want to confront the possibility that despite their confidences to the contrary, the geography and wildlife of the West still posed threats to 
their health and welfare (Pomeroy 70).

Despite the differences between Yosemite and Yellowstone, the marketing strategy was the same. Images that emphasized the dramatic landscape and scenic grandeur of the west proved effective, especially when supplemented with promises of exquisite lodging and fine cuisine after a day of touring. Curiosity about Yellowstone was as prevalent as interest in Yosemite, but the much wilder and more remote territory in the region posed threats which Northern Pacific had to contend with in its advertising. In 1877, a visiting tourist was killed when he was caught in a skirmish between Chief Joseph's Nez-Percé men and the U.S. Cavalry during an army reservation drive which had gone awry when the Nez-Percé led the government troops on a 500-mile chase through the Yellowstone territory during part of an intense four-month battle between the two sides. The amount of wildlife in the park also confronted the "civilized east" with the presence of untamed and unfamiliar nature in its most threatening form; even then, bison and moose had the reputation of being temperamental and surprisingly fast animals. To the sophisticated traveler of the 1880 's, wildlife and the Native American were synonymous, and the presence of either at a vacation resort detracted from its overall appeal.

Beyond these obstacles, there was the issue of Yellowstone's landscape, which was hardly on the order of Yosemite or Switzerland. Although it was unarguably unique and stunning in its curiosity, the land alone would not appeal to the refined tourist who frequented Yosemite. One early visitor wrote of the park that "there was something so revolting in the general appearance of the springs and their surroundings, the foulness of 
the vapors, the noisy ebullition, the general appearance of desolation, and the seclusion and wildness of the location that, though awe-struck, we were not unreluctant to continue our journey without making them a second visit" (Pomeroy 53). Other early visitors seconded the opinions of these tourists, and many agreed with one journalist when he wrote that "it is a mistaken idea that Yellowstone abounds in grand scenery" (Pomeroy 53).

For what Yellowstone lacked in majesty and sublimity, it more than compensated for in curiosities. Topography unlike any other region in America became the most prominent feature of the area, and in the 1880's and 90's, Yellowstone was marketed as the uniquely American landscape where vestiges of the Wild West would remain preserved and protected forever, thanks to its unique status as America's only national park. Northern Pacific's marketing strategy followed the style of Buffalo Bill's Wild West Show by emphasizing the carnivalesque atmosphere of the park. The Wild West Show featured buffalo, Native American actors, and theatrical performances of "authentic" Wild West events and activities, and Northern Pacific felt that it could create a living Wild West Show in Yellowstone. In response to the abundance of natural phenomena within the area, Northern Pacific adopted the nickname "the Wonderland Route" for its line to Yellowstone and began to tout its unparalleled reserve of animal life, scenic splendor, and "wondrous and curious freaks of Nature," thereby turning Yellowstone into a natural amusement park for the nation's elite.

Beginning in 1886, the railroad sponsored the construction of several sumptuous hotels in the Yellowstone area to heighten the park's appeal for the wealthy. Access 
within the park's borders, thanks in large part to Langford's rail-biased park management, was one advantage Northern Pacific had over Southern Pacific in the promotion of its wonderland. Both the Gardiner gateway station and the Livingston terminal of the main rail line sported log cabin style architecture of Northwest timber and quarried stone and borrowed local folk decorating styles which recalled frontier days by employing such items as wagon wheels for use as hanging lights or table supports and bearskins for rugs. This style was echoed again at the Mammoth Hot Springs Hotel and later at the Old Faithful Inn. Both hotels won accolades for their fine food and exquisite accommodations. Mammoth Hot Springs was referred to as "The Last Outpost of Civilization" by rail officials and visitors alike, and The Old Faithful Inn was the first inn built in the park boundaries and remains the most popular today.

Rail executives often invited influential men and their parties to travel the area with the Northern Pacific stage guides and enjoy the park compliments of the railroad. These guests were well-heeled corporate men from the east affiliated with businesses that could assist the marketing efforts of the railroad: bankers, speculators, and publishers were often honored guests. Sometimes the railroad would invite journalists and writers to join them in the park, often early in the summer, so that these men could publish articles on Yellowstone in enough time to encourage late-summer travel to the West. To assist the cause and to ensure desired publicity, Northern Pacific always offered the services of the railroad's official photographer, Frank Jay Haynes. Haynes was also the author and illustrator of the immensely popular Yellowstone Park Illustrated tour guide which was published by Northern Pacific and freely distributed around the east. Haynes provided 
Northern Pacific with an extensive collection of photographs which the railroad then used in photo exhibitions, magazine articles, and paid "documentaries" about the geology of Yellowstone. Thanks to the photographic work of Haynes, Yellowstone--and the Northern Pacific--remained in the public spotlight for years.

The earliest days of park tourism reflected the needs of the railroads as much as it did the demands of the tourist who visited Yosemite and Yellowstone. In these Western parks, the railroads discovered a new way to cater to the investor by taking advantage of growing interest in the strange and majestic Western landscape and then representing it in familiar ways to the target market. For Southern Pacific, Yosemite was Switzerland remade in America, and remade on a grander and more sublime scale. Yellowstone, on the other hand, was a theatrical sideshow of curiosities for the wealthy to view. In both cases, the parks were strictly business for the railroads, and they used these spaces much in the way businesses of today use a golf outing at a country club to woo potential clients and shareholders. This class of tourist did not engage actively with nature, but gazed at it from the coaches that drove them from attraction to attraction before returning them to the comfort of places like the Old Faithful Inn. The influence of this kind of tourist remained in the parks, but as the demographics of the West and the nation changed, the needs of the railroads changed too, and they needed new strategies to keep their passenger lines in business. 


\section{Expanding the Market, 1883-1900}

By the early 1890 's, visitation to both Yosemite and Yellowstone had increased steadily each year, but the numbers reflected the limited tourist market the railroads had targeted. Only the wealthy could afford the passage, and many of them were more interested in visits to urbane San Francisco, lavish Monterey, or nouveau riche Los Angeles. By 1890 , no new parks had been nominated or preserved, and it seemed that they were a phase of the past until new cultural trends and national concerns as well as the changes in America's economy and population presented new opportunities and needs for the railroads. The tourist in the 1870's was first targeted as a potential investor and settler, but in the 90's the tourist was simply a visitor who needed to be persuaded to ride the rails west year after year for vacations. Even though the urgency of attracting investors had subsided, the railroads had invested in park accommodations and passenger equipment. The structures for tourism were in place, and the railroads began a mass-marketing strategy that appealed to a much wider market of tourists than the elite investors of the 1870 's.

The American west had changed in the twenty years since the railroads had entered the unsettled wilderness beyond the Rockies. By this time, the West was not nearly as wild as it once had been, and vestiges of the old west vanished rapidly in the flurry of new settlement. As early as the mid 1880 's, Northern Pacific engaged in active marketing strategies to demonstrate that the West had come of age and that the badlands of the North had at last bent to the will of the plow. In 1883 an exhibition car called the 
"Fair on Wheels" made its way from Minnesota throughout the East to display minerals, timber, and specially made stuffed animals representative of Yellowstone's species along with fruits, grains, and potted plants indicative of the bountiful harvests of the old Northwest--all made possible by the railroad. Over 400,000 people visited the car and took away promotional literature about the "Yellowstone Park Line," its hotels at Mammoth Springs and Old Faithful, and the names of the nearest ticket agents. Throughout the 80's, Northern Pacific circulated travel brochures in the East that promised the best of both worlds--an "authentic" wild west experience in a wilderness made safe, prosperous, and civilized by the railroad. Although the railroad estimated a distribution of two million pieces of promotional literature about Yellowstone, visitation to the railroad car was considerably higher than visitation to the park, which averaged only about 500 per season, largely because of the tremendous expense of travel West. Still, the "Fair on Wheels" stunt indicated to the railroad that there was enough public interest in the West to consider opening travel to a mass market in the near future. (Kinsey 75).

As Northern and Southern Pacific made payments on their outstanding debts and enjoyed economic success in the freight business, it was time to reconsider the parks. They had invested millions in construction, passenger cars, and advertising, and now that the search for investors had slowed, something had to be done to stimulate interest in travel to the parks. Again, the railroads were able to take advantage of America's fascination with the West to increase tourism on a mass scale. In 1890 , the Census reported that there was no longer a distinguishable frontier line in the United States, and 
settlement spread from coast to coast. This pronouncement had an uncertain but uneasy effect on Americans. After more than 250 years of an ever-present wilderness which existed beyond a settled point of civilization, Americans faced at last the realization of the nation's "manifest destiny" to spread from Atlantic to Pacific. Although the importance of this event would not be analyzed until Frederick Jackson Turner presented his speech 'The Significance of the Frontier in American History" at the World's Columbian Exposition in 1893, many Americans understood that the country had reached a milestone in its development. Coupled with the rise of the urban East and the manufactured detritus of industrialization which polluted the cityscapes and encroached upon the surrounding countrysides, it seemed as though the announcement of the Census suggested the loss of a significant portion of America's cultural identity. The same Census report also indicated a depleting amount of timber and arable lands in the public domain, adding the insult of declining material resources to the injury of a vanishing cultural resource. The thought that the American wilderness--and the American identity by implication--were in jeopardy spurred a cultural revolution of sorts which embraced the preservation of nature in order to protect American history and prosperity. In 1890, President Harrison signed the Forest Reserve act to protect remaining timber in the West, and Yosemite and the adjacent Sequoia groves won federal protection, making it the nation's second National Park-thanks to a little help from Southern Pacific.

The proclamations of the 1890 census impacted popular attitudes toward America's wilderness now that many felt it was vanishing, but American society had also changed dramatically since the 1870 's. Rampant industrialization rapidly overtook towns 
and cities alike throughout the eastern part of the country. The infamous Tammany Hall government of New York was representative of urban management in its neglect of city maintenance and sanitation. Photographer Jacob Riis documented the decay of New York's streets in publications like Harper's Weekly and exhibited his photos around the country to dismayed audiences from Philadelphia to Chicago--all of whom recognized a degree of Tammany neglect in their own cities. Images of the West, however, still maintained the promising luster of virgin land. Photographs of the Western landscape circulated in the east and provided the ideal alternative to the photos presented by Riis. The East strained under the weight of industry and population, but the West was still fresh, open, and new--or so the photographic dialogue between Western photographers and Riis suggested.

In addition to the census findings and the increasingly industrial East, the popular arts were inventing their own versions of the West which were sold to a mass audience eager to buy them. Dime novels that told adventurous tales of fiercely independent cowboy heroes, lawless bands of shooters and thieves, or romances between cowhands and rancher's daughters created their own mythical visions of a wide-open West that sounded more appealing than the decaying urban neighborhoods where many readers of these books lived and worked. During the 1880's and 1890's, Buffalo Bill's Wild West Show toured the country and brought similar visions of the West to the East and expressed them in the three dimensions of the theater. The products of popular culture brought images and ideas of the West to the minds of the masses just as the paintings of Moran and Bierstadt and stories in Harper's conveyed a vision of the West to the elite 
audiences during the 1860 's and 1870 's. As increasingly romanticized notions of the West emerged in the national consciousness through these other avenues, the railroads found a new way to appeal to a mass market by selling a romanticized version of travel on the old frontier.

In 1893, the World's Columbian Exposition provided a mass market audience to target for visitation to the parks. Both Yosemite and Yellowstone were represented at the Fair, but because Northern Pacific had easy rail access from Chicago to Yellowstone, the line took advantage of the number of travelers already attending the fair and encouraged continued travel west to Montana and Washington. Once tourists visited the spectacle of technology and industry, they could ride the rails to the source of American innovation and ingenuity and commune with the wilderness in the comfort and style made possible by the railroad industry. In order to symbolize this "best of both worlds" invention, the Northern Pacific adopted the Chinese yin-yang, symbol of the balanced universe, as its logo. This choice not only suggested harmony between nature and industry and wilderness and civilization, but it also reminded the public that Northern Pacific had expedited the manifest destiny of America by building the transcontinental link to the Orient, the fabled "Passage to India."

Southern Pacific engaged in similar promotion during this time, emphasizing its access to perennially popular San Francisco and newly fashionable Los Angeles. Playing even further to its niche-market of sophisticated travelers, Southern Pacific sponsored the publication of Sunset, "the Magazine of Western Living," which was a lifestyle magazine with decorating tips, garden advice, fashion updates, and popular fiction set in the West 
which became one of the most ingenious marketing strategies employed by the railroad. The magazine was distributed on both coasts, but Southern Pacific played down its role in the publishing process enough to leave many readers unaware that they were subscribing to a railroad publication despite the full-color ads for Southern Pacific's passenger routes sprinkled liberally throughout each issue. After reading about the splendors of California; readers intrigued enough to visit the state knew precisely how to get there.

Sunset offered proof that the west was civilized and that America had achieved its destiny by bringing style and culture to the Pacific coast. California glittered with the luster of a promised land in the pages of the magazine. It had the elite culture, palatial hotels, and epicurean delights of San Francisco; the sublime scenery of the Yosemite; ports with access to the Orient; and even a land of deserts and orange groves, proof enough for some that California was indeed the New Jerusalem. Sunset enjoyed such widespread popularity that it is still published today, although Southern Pacific relinquished its rights to an independent publisher after the company abandoned passenger service.

Northern and Southern Pacific each adopted prominent spokesmen during the 1890 's in order to keep their companies and their parks in the limelight. Southern Pacific co-opted John Muir as a chief publicist because of his passionate involvement with Yosemite, but Muir was a reluctant accomplice. Muir's popularity with preservationists and his well-known favor of an officially legislated system of protected wilderness provided Southern Pacific with free publicity and an opportunity to align itself with his beliefs to show the public how important their association with Yosemite was in 
maintaining the valley's protection. Northern Pacific associated itself to ardent sportsman Teddy Roosevelt in order to capitalize on his outspoken pleas for more areas of federally protected wildlife and wilderness. Neither Muir nor Roosevelt had any interest in building an association with either railroad, but the railroads readily took advantage of the popularity of these two men by echoing their opinions in new advertising strategies designed to advance their own interests in targeting new tourist markets.

Muir, Yosemite's most celebrated resident and the park system's most ardent defender, was writing and speaking often about the merits of preservation based on on ecological values alone. He had criticized the "blank, fleshly apathy" of the class of tourist that visited Yosemite in its early years and loathed the passive and consumptive role played by wealthy visitors who came to nature for nothing more than contemplation, conversation, and convalescence--a role encouraged by Southern Pacific's advertisements (Pomeroy 52). Muir was instrumental in winning National Park status for Yosemite in 1890, but he conceded that "even the soulless Southern Pacific Railroad, never counted on for anything good, helped nobly in pushing the bill for the park through Congress" (Runte TD 33). Muir's deep ecological beliefs were far ahead of his time, but slow increases in visitation and burgeoning interest in the West made the railroads as determined as ever to protect these parks and seek new ones for protection. Although Muir was opposed to the kind of tourism encouraged by the railroads, he understood that ecological defenses for preservation would not win popular or congressional support. An unlikely but effective alliance developed between Muir and Southern Pacific. The railroads had the means to bring influential people to the parks, and through high 
visitation and higher profits the railroads could demonstrate the economic value of scenery. As the benefits from railroad profits created more jobs and more resort areas, the preservation movement would gain a strong defense for its cause.

The problems in the East and the promise of the West helped contribute to the rise of the "Wilderness Cult," a trend which appealed to many who favored the outdoors and looked to the "simpler, more ordered world of Mother Nature, where life adhered to nobler principles" (Demars 46). Muir's famous Sierra Club formed from a group of concerned Californians who worked tirelessly during the park bill debates. Once Yosemite was protected, the group became actively involved in interpretive visits to the park which involved wildlife study, back-country hikes, and camping excursions. Wilderness groups emerged East and West, motivated by a common belief that wild nature was the source of abstract notions such as beauty and spiritual truth--qualities threatened by both the utilitarian approach to nature as an economic resource and the Romantic tourist approach to nature as an entity to conquer and imprint with the comforts of civilization. Shifts in tourist approaches were slow to come, but throughout the 1890's, outdoor enthusiasts entered Yosemite and Yellowstone as often as the high society tourist, and outdoor camps were constructed opposite the plush hotels sponsored by the railroads. Tourism was changing, and the railroads recognized the need to expand their market to include this new breed of park visitor.

In 1896, Southern Pacific became the first railroad to accommodate the new tourist by reducing fares enough to appeal to a middle-class clientele and even checking camping equipment free of charge. Now, visitors from the East could haul tents, 
cookstoves, and lanterns to Yosemite. New camps were constructed with rough but pleasant accomodations, and all visitors were encouraged to participate actively in wilderness adventures. Hiking, bird-watching, boating, and overnight back-country excursions provided visitors with an opportunity to experience the parks on a more ecological basis--at a price considerably lower than the Pullman-to-hotel journey purchased by the wealthy. Despite the different emphasis of the nature tourist, Muir's Sierra Club blended harmoniously with Yosemite's reputation of a "civilized wilderness," and Southern Pacific was able to continue marketing the park as a moving and nearly divine landscape even though experiences of Sierra Club participants and Hutchings hotel guests were markedly different.

Northern Pacific took advantage of Theodore Roosevelt's popularity as a wilderness advocate and turned him into the unofficial spokesman of Yellowstone. Roosevelt, contrary to Muir, was the rough-and-ready sportsman, an easterner who remade himself into a pioneer after buying a ranch in the Dakota territory. Where Muir espoused deep ecology and respect for leaving nature to its own devices, Roosevelt was an avid hunter and explorer who shared only a love for wilderness and a respect for preservation with Muir. Roosevelt's "Boone and Crockett Club" appealed to others who shared interests in big game hunting and forestry preservation. Although the club's manifesto included objectives such as "promoting manly sport with a rifle" and "promoting travel and exploration in the wild and unknown or partially unknown parts of the country," Roosevelt also intended the club to work for preservation of big game animals in order to control the populations and impose stiff penalties for poachers who 
defied the protection boundaries of Yellowstone when hunting (Harper's Weekly 37:1881). Roosevelt was as interested in preservation as Muir, but his approach emphasized the wild in the west, in keeping with the differences established between Yosemite and Yellowstone.

Northern Pacific sided with the future president and worked with the preservationists in the Northwest just as Southern Pacific did in the Southwest. In traditional Northern Pacific fashion, railroad officials created publicity for wildlife protection in America, beginning with a proposed expansion in Yellowstone that would ensure a preserve for migratory wildlife during the winter. When land speculators in Cooke City, Montana lobbied for permission to mine ore on the border of the park, Northern Pacific and Roosevelt opposed vehemently and gained editorial support from the popular press. An 1893 issue of Harper's featured an editorial on the issue that praised Northern Pacific's stance, saying that "if the people of the United States took in this national park the same kind of interest that people in New York and Philadelphia take in Central and Fairmount Parks, there would be fewer efforts made to encroach upon it," which appealed to the sensibilities of Easterners by couching the argument in terms of the city parks they enjoyed (Harper's Weekly 37:1892 2). Northern Pacific president Terry Oakes declared in the same article, "let the vandals once get a foothold in it... and there will be nothing worth preserving" (3). Sixty years later, well after the railroad passed its heyday, Jackson Hole and Grand Teton were annexed to Yellowstone and Northern Pacific received full credit for the idea initially proposed by passenger agent Olin D. Wheeler in a 1902 issue of Wonderland magazine, the Sunset of the Northern Pacific 
(Runte TD 24).

Roosevelt was instrumental in bringing the value of preservation to the attention of the public, and his practical perspective on wilderness won the approval of many influential citizens. Roosevelt saw the wilderness as something the nation could and should use for economic development, but his emphasis was on wise and controlled use. To him, the failure to use available resources was as wasteful as exploiting them without regard for future need and availability. His association with Northern Pacific railroad, although unintentional and unofficial, worked to the favor of the railroad. Now the Northern Pacific was able to market their expanded passenger service to include wilderness tourists, and Yellowstone succeeded in becoming a sportsman's paradise and a camper's dream.

Lower fares and increased interest in wilderness brought new visitors to the parks each year. Preservation was popular, and new railroads followed the precedents of Yosemite and Yellowstone to discover and invent playgrounds along their lines. The Santa Fe Railroad adopted the Grand Canyon in Arizona, the Utah valleys, and ancient Native American ruins; the Great Northern worked with Glacier National Park almost as aggressively as Northern Pacific promoted Yellowstone; and the Burlington Northern promoted the Dakotas and Wyoming. If the land the rails sought for protection was worthless for valuable resources but featured majestic and monumental scenery, protection was justified because the railroads demonstrated that scenic preservation in Yosemite and Yellowstone was indeed profitable for the nation. Although personal profiteering was forbidden in any National Park, protection was not "inalienable." Future 
development in National Parks was limited to profit which was in the "national interest," meaning that if natural resources in the park could provide more benefits to the economy than the railroad-related profits could, protection would be repealed. Runte notes that this distinction between valid and illegitimate development marked the double standard of the National Parks: "the sin of exploitation was not the pursuit of personal gain, but personal gain that could not be defended as being in the national interest" (Runte NP 53, emphasis mine). Tourism, of course, could be defended as being in the national interest because the railroads were providing the means for all Americans to commune with a preserved monument to their cultural history, thus uniting profit with patriotism.

\section{Boom Times in America's Playgrounds, 1900-1916}

By 1900 , the parks were extremely popular and park accommodations filled to capacity summer after summer. Despite lower fares and appeals to a broader target market in advertising, train travel was still costly. Additionally, all national park, which now included Sequoia, Crater Lake, and Mt. Rainier, were in the West, far from the major population centers. By 1905, visitation in Yellowstone only totaled 13,000, with Yosemite's only slightly higher because of its proximity to San Francisco.

Preservationists and railroad executives alike faced a difficult task in defending the profitability and popularity of the parks well enough to convince the government that economic resource exploitation was not a more worthwhile approach to the American wilderness. 
For all that men like Muir and Roosevelt had accomplished in bringing the issue of preservation into the national discussion, they were not able to remove the clause leftover from the National Park bill that granted Congress the power to repeal protection from National Parks where economic development was feasible. The preservationists felt vindicated when the Yosemite Valley won National Park Status in 1890 and was given 1500 additional acres of timber and grasslands along the foothills of the Sierras, but in 1905 local timber companies and farmers lobbied ardently enough to reclaim valuable timber, grazing, and mineral areas totalling roughly 540 square miles, one-third of the protected land (Runte, NP 56). This reversal of federal protection did not bode well for preservationists. John Muir and others objected strenuously to park reduction, but they could not defend the foothills from economic exploitation by claiming them as National Monuments; they were not the rugged peaks of the Sierras or the centuries-old antiquities of American history. They were simply not majestic enough to qualify as monuments to America.

Shortly after this strike against Yosemite, the city of San Francisco dealt another blow to the ecological safety of the valley. San Francisco was in search of a fresh water source and after years of looking, the city settled on the Hetch-Hetchy Valley which lay in the boundaries of the National-Park. Preservationsits claimed that Hetch-Hetchy was equal to Yosemite in its sublimity and splendor but not many visitors had seen it because access to Hetch-Hetchy was limited to rough trails which most park tourists did not explore. Despite the outspoken protests against the suggestion to dam the valley for a reservoir, the needs of 500,000 San Franciscans took priority over the few hundred 
tourists who visited each summer. Late in 1905, Secretary of the Interior James A. Garfield approved San Francisco's request and permitted a dam in the gorge.

The contest between the aesthetic and ecological character of Yosemite and the practical needs of 500,000 California residents shows that the railroads may have met with too much success in their efforts to promote travel and settlement in the west. In the early 1900 's, the West had been settled. Early rail campaigns and government land rushes drew hundreds of thousands from Europe and the East coast, and cities and towns were arising from the prairies, deserts, and mountains by the moment. Former outposts such as Seattle and Portland developed into powerful Western communities with urgent practical needs. A double standard emerged in the country that still persists. The west had been a place of such cultural importance that its national parks and forest reserves seemed crucial to the protection of an American identity. Even after the burgeoning Western population demonstrated an economic need for resources and land, their need to earn a living and build communities remained secondary to the preservation of an idea of an American past. Eastern land was readily sacrificed for economic development, but the West was more a living museum than a place to live and protection was and is a more prominent question in Western states.

Despite their possible culpability in the matter, rail executives and preservationists worried that the Hetch-Hetchy debacle was the death knell for the parks. Preservationists renewed fears of ecological decimation in the well-preserved West and railroad officials feared massive finanical ruin from the failure to capitalize on the significant investments in park accommodations, advertising, and passenger car upgrades. With the threat of 
losing the parks to economic devleopment, the railroads and the preservationists cemented their relationship and worked to keep these regions intact. The rails responded accordingly and increased advertising which courted the nature tourist and the society tourist alike to keep the crowds coming. Preservationists continued to lobby for a central park management authority and permanent protection in each park, and the railroads did their part to heighten interest in a wilderness vacation. The "See America First" campaign was devoted to the national park cause, and the appeal to patriotism was one of the most successful marketing strategies the railroads concocted. If the parks were to be protected, the rails reasoned, people had to visit them. "See America First" addressed the pervasive cultural anxiety about America's ability to compete with Europe for visitation and encouraged travel to the American West instead of the Alps or other European destinations.

The advent of the automobile also spurred the railroads into action, since the luxury of the Pullman could hardly compete with the notoriety and novelty of a personal car, at least among the very wealthy clientele long courted by the railroads. Nonetheless, the railroads continued to devote funds to park enhancements. Southern Pacific had recently built the glamorous Del Portal Hotel just outside Yosemite's border and announced plans to make a connection with the newly organized Yosemite Valley Railroad, the first rail line to provide direct access to the valley, thus making the difficult stage journey into the park obsolete. Northern Pacific poured money into upgrading Yellowstone establishments and worked to maintain its association with the park in light of the new competition presented by the arrival of the Chicago, Milwaukee, and St. Paul 
line at the new "Gallatin Gateway" on Yellowstone's west side.

With new railroads duplicating the Northern and Southern Pacific examples in new parks across the West, establishing a centrally managed and permanently protected National Park System became crucial for protecting railroad investments in advertising and park facilities. The Hetch-Hetchy affair proved that Congress would readily invoke its right to exploit the resources in the park if necessary, and rail officials and preservationists alike feared for the integrity of their parks and profits. The public needed an impetus to champion preservation, and railroad agents and preservationists found their spokesman in horticulturist, printer, and publisher J. Horace McFarland, a Pennsylvanian with a dedicated interest in preservation. He was able to use his position and his pen to elicit support through the popular press. The Ladies' Home Journal, Century, and Outlook magazines featured McFarland's columns which encouraged support for scenic protection based on worst-case-scenario appeals to preserve "America's heritage." In his wildly popular "Beautiful America" column, he wrote in support of preservation by reminding the public again of Niagara Falls, calling it "The Monument of America's Shame and Greed" (Runte, NP 87). McFarland's effectiveness in the matter was his support for profit from preservation, and his approach appealed to economically minded citizens and preservationists alike as he criticized the downfall of Niagara in financial terms by reminding Americans that their scenic wonders brought them millions of dollars in tourist revenues in and out of the park boundaries each year. This reminder of the associative property of park profits in surrounding communities was effective. Even though preservation on environmental grounds was not easily defended at this time, economic 
appeals guaranteed ready approval from the public.

Because of the publicity in the popular press, along with opinions like McFarland's, scenic preservation gained the popular support it needed and park visitation rose sharply in the the 1909,1910 , and 1911 seasons. Preservationists agreed with McFarland's anti-development stance, and businessmen were inspired by his reminder of the tourist dollars at stake. In 1911, when the first National Parks Conference convened at Yellowstone to discuss the problematic park management policies, the railroads devoted their energies exclusively to the preservation effort. The presence of several rail delegates demonstrated to the preservationists that their cause was about to reach its peak. Thanks to what Secretary of the Interior Walter Fisher referred to as the "enlightened selfishness" of the railroads, an organized and effective National Park System seemed a reality. For the railroads, years of continued profits and free publicity seemed a guarantee. Until the automobile became affordable in the late 1910 's, the Railroad and National Park alliance was a win-win situation for businessmen, conservationists, and tourists.

The news about the proposed National Park Service generated new interest in park visitation. By 1905 , only 13,000 people had visited Yellowstone since its dedication in 1872. During the summer of 1915 alone, 51,895 visitors entered the park and 45,000 of them arrived by Northern Pacific to stay in railroad lodges and take advantage of railroad tours (Runte TD 28). Yosemite was more popular during the early 1900 's, managing to attract about 5,000 visitors annually, but once the National Park issue reached the public spotlight, its numbers soared to nearly 50,000. Southern Pacific took advantage of the new Yosemite Valley Line, advertising "Pullman Service All the Way" from Los Angeles 
to El Portal, and the small railway shuttled nearly 15,000 passengers through the Merced River Canyon to the valley (Runte, TD 54).

With figures like these, the profitability of preservation was undeniable. Railroad testimonials during congressional hearings were instrumental in winning governmentally legislated protection of America's scenery. President Woodrow Wilson signed the National Park Act in 1916, and fifty years of railroad efforts culminated in the largest system of federally protected land in the world. When the automobile arrived to "democratize" long-distance travel in the following years, the new auto tourist had vast public spaces to experience because of the aggressive railway campaigns and the communities which surrounded the National Parks enjoyed stable economic prosperity from the yearly barrage of travelers and their tourist dollars. The railroads could not have imagined their rapid downfall after the automobile's ascent, but their persistence in acquiring and protecting national park lands and the images they implanted in the national consciousness left a legacy that transcends their economic motivations. 


\section{Conclusions}

Although the rails no longer carry passengers, their advertising legacy lives on in the brochures distributed by the National Park Service. Yosemite is still considered a Romantic tourist's resort, where the wealthy stay at the tony Ahwahnee Hotel and play golf behind a chain link fence at the base of the Sierras. Vestiges of Muir remain strong too, andYosemite is also the deep ecologist's national park where spired peaks and mighty waterfalls fill visitors with awe and respect for nature. Images of Yellowstone still feature the canyon of the Lower Falls from Moran's perspective, and the park still exudes an appeal for the wild west tourist who seeks an outdoor experience on the order of the Boone and Crockett Club.

Northern and Southern Pacific left more than magnificent public spaces and enduring publicity strategies to the American public. The national parks provided both the railroads and the American public with the most complete expression of America. Yosemite and Yellowstone were both monuments to American nationalism which battled for primacy over the exploitation of free enterprise but were finally protected because of the profit potential realized by the railroad industry and tourist trade. Despite concerns about commercialization, Americans were ready and willing to purchase an idea of cultural heritage in the dramatic landscapes of the West. The railroads did not create public curiosity about American scenery, but they did create a particular story about the landscape by selling scenery as a cultural asset. For millions of Americans uneasy about their country's heritage, the railroads helped to locate and then continually reaffirm a 
strong sense of national pride in the Western landscape. For many other Americans who denied the wilderness any value beyond strict utilitarianism, the railroads opened a new motive for profit and demonstrated through their "enlightened selfishness" that the majestic, stunning, and often exotic lands of the old frontier were indeed one of the country's most significant historical treasures.

Most importantly, the railroads shaped an idea of the American West as a region in which America could redeem itself culturally and economically. Until the 1920's, protected land lay exclusively in the West, and the enduring images of mountain vistas, roaring rivers and falls, and dramatic canyonlands competed with images of death, disease, and decay in the East. These images suggested that resources were ample, land was plentiful, and possibility was infinite in the landscapes of the West. The railroads encouraged the belief that they followed the wagon train through the "virgin land" and brought civility, fertility, and prosperity to the frontier while preserving what Runte calls "the imposing backdrops" in which Americans "played out their final act of territorial development" (Runte TD, 11). The protection of the Western landscape ensured that America would always have an opportunity to renew itself through recreation in these culturally important parks and the railroads believed that they would always be the singular agent of deliverance in this cultural reenactment.

The images and the ideas generated by the railroads persist, even though America's "Romance of the Rails" has turned to a love affair with the automobile. Northern Pacific's Yellowstone and Southern Pacific's Yosemite have become the two most visited parks in the nation, averaging over 2 million visitors per year. As 
contemporary park management debates over the ecological strain of the automobile and the crush of summer tourists escalate, the National Park Service is reconsidering the railroad. Rail service has been reinstated at the Grand Canyon, Mt. McKinley, and in Colorado's Front Range. Yosemite officials have recently suggested the restoration of the Yosemite Valley Railroad, and Amtrak's Empire Builder may find renewed popularity because of its direct access to Glacier National Park in Montana. Accolades for the revival are as plentiful as passengers who come to relive the experience of train travel as a part of the journey instead of just a means to the destination. As we turn the next century, Americans may rediscover their country by rail, heeding the romantic and evocative call of "All Aboard!" 


\section{Works Cited}

1. Poor, Henry V., Manual of the Railroads of the United States: 1870-1871 (New York: Adams Express Company), 1871.

2. Harnsberger, John L., Jay Cooke and Minnesota: The Formative Years of the Northern Pacific Railroad (New York: Arno Press), 1981.

3. Runte, Alfred, National Parks: The American Experience (Lincoln, Nebraska and London: University of Nebraska Press), 1979.

4.Anderson, Nancy K., Albert Bierstadt: Cho-Looke, The Yosemite Fall (San Diego: Timken Art Gallery), 1986.

5.Anderson, Nancy K., and Linda Ferber, Albert Bierstadt: Art and Enterprise (New York: Hudson Hills Press) 1990.

6.United States Department of Interior, The National Parks: Shaping the System (Washington: United States Printing Office), 1991.

7.Unknown, "The Yellowstone," in Harper's Weekly, January 7, 1893; Volume XXXVII, No. 1881.

8. Kinsey, Joni Louise, Thomas Moran and the Surveying of the American West (Washington and London: Smithsonian Institution Press), 1992; 58.

9. Haines, Aubrey L., Yellowstone National Park: Its Exploration and Establishment (Washington: United States Department of the Interior), 1974.

10. Wilkins, Thurman, Thomas Moran, Artist of the Mountains (Norman, OK: University of Oklahoma Press) 1966; 6.

11. Pomeroy, Earl, In Search of the Golden West: The Tourist in Western America 
(Lincoln and London: University of Nebraska Press), 1957.

12. Runte, Alfred, Trains of Discovery: Western Railroads and the National Parks (Niwot, Colorado: Roberts Rinehart Publishers), 1990.

13. Demars, Stanford E., The Tourist in Yosemite, 1855-1985 (Salt Lake City: University of Utah Press), 1991.

14. Harper's Weekly, March 18, 1893; Volume XXXVII, No. 1892.

\section{Bibliography}

Lucius Beebe, The Central and Southern Pacific Railroads (Berkeley: Howell North) 1963.

Katherine E. Early, For the Benefit and Enjoyment of the People: Cultural Attitudes and the Establishment of Yellowstone National Park (Washington: Georgetown University Press) 1984.

The Henry Art Gallery, Myth of the West (Seattle: University of Washington Press), 1989.

Sig Mickelson, The Northern Pacific Railroad and the Selling of the West: A Nineteenth-century Public Relations Venture (Freeman, SD: Pine Hill Press), 1993.

James D. Norris, Advertising and the Transformation of American Society, 1865-1920 (New York: Greenwood Press), 1990.

Jules David Prown, et al, Discovered Lands, Invented Pasts: Transforming Visions of the American West (New Haven and London: Yale University Press), 1992.

David Robertson, Yosemite As We Saw It: A Centennial Collection of Early Writings and Art (Yosemite National Park), 1990. 
Charles R. Wood, Northern Pacific: Main Street of the Northwest (Seattle: Superior Publishing Company), 1968. 